\title{
About the usefulness of employing the models of the Church in the study of canon law
}

\author{
Piotr Kroczek \\ The Pontifical University of John Paul II in Cracow
}

\section{Introduction}

It can be said that the Church is a society where law plays very significant role. There is no Church without law because law belongs to the Church's nature and provides means to achieve the aims that the Church has. As it was said by the Pope John Paul II in the Praefatio to Codex Iuris Canonici from 1983: „(...) sana ordinatio iuridica prorsus necessaria est ut ecclesiastica communitas vigeat, crescat, floreat ${ }^{1}$.

The Founder of the Church, Jesus Christ, wanted for the law to express and organize the structure of the Church as a divine-human reality $\left(L G^{2} 8\right)$. The reality in question has legal elements as its inseparable parts and as conditions of being the genuine Christ's Church. During the Second Vatican Council the Church described itself as communio. The Church is communion of life, love and truth ( $L G 9$ ). Nota explicativa praevia to $\mathbf{L u}$ men gentium in no. 2 explains how to understand that expression. It is not understood as some kind of vague disposition but as an organic reality, which requires a juridical form and is animated by charity ${ }^{3}$.

The Church and its law must always be seen in mutual harmony and should be fathomed out together. The Church cannot be deprived of its

\footnotetext{
1 Praefatio to Codex Iuris Canonici auctoritate Ioannis Pauli PP. II promulgatus, Acta Apostolicae Sedis 75 (1983) II, p. XVII-XXX; here p. XXX: „(...) a healthy juridic organization is quite necessary for the ecclesiastical community to live, grow and flourish". English translation taken from: Code of Canon Law Annotated: Prepared under the Responsibility of the Instituto Martín de Azpilcueta, ed. E. Caparros, M. Thériault, J. Thorn, H. Aubé, $2^{\text {nd }}$ ed., rev. and updated of the $6^{\text {th }}$ Spanish language edition, Montréal 2004.

2 Sacrosanctum Concilium Oecumenicum Vaticanum II, Constitutio dogmatica Lumen gentium de Ecclesia, 21.11.1964, Acta Apostolicae Sedis 57 (1965), p. 5-75.

${ }^{3}$ Nota explicativa praevia, no. 2: "Communio (...) Non intelligitur autem de vago quodam affectu, sed de realitate organica, quae iuridicam formam exigit et simul caritate animatur". A. Slodička, Theologia fundamentalis de Ecclesia, Prešov 2005, p. 5-9.
} 
law, because it would mean loosing identity by the Church. Also anyone who studies church law cannot do that separately from the Church. Canon law has genuine ecclesiological roots ${ }^{4}$. Any extrapolation of canon law from its origins would cause the cognition of the law to be incomplete.

The Second Vatican Council decreed that the teaching of canon law should take into account Mysterium Ecclesiae (OT 16 ). On this basis it can be said that dealing with canon law, here understood both as the phenomenon and as the regulations in the Church, must be preceded by considering the Church itself. ${ }^{6}$ Proper comprehension of the Church makes it possible to understand the sense of canon law not only as a system of regulations, but as relevant element of life of community of believers. It must be underlined that in the community of the Church lex fidei is seen as lex disciplinae. Members of the community in question are obliged to obey norm mainly because the faith requires certain way of behaving ${ }^{7}$. In the Church, due to its uniqueness, legal norms put on its addresses not only legal obligations but also moral ones.

Considering that the Church is a multilevel and a very complex reality, it is advisable, while exploring the Church, to work with a model of the Church. Thanks to the use of such a model, recognizing and understanding the Church becomes not only doable but also efficient.

The article is a modest try to approach the subject of a model of the Church in the perspective of canon law. It is based on conviction that to get to know the Church and its law, a model of the community of believers is required. It is because canon law is rooted in self-consciousness of the Church as living body that is continuously enriched by the changing world and inspired by the Holy Spirit. ${ }^{8}$ The article aims to show some models of the Church and to present thoroughly Sobański's model of the Church as the efficient tool for canon lawyers? ${ }^{9}$. It also contains the grounds for choosing of this model.

\footnotetext{
4 About the ecclesiology of canon law, see: R. Sobański, Podstawy prawa Kościelnego, Prawo Kanoniczne 34 (1991), no. 1-2, p. 13-24.

5 Sacrosanctum Concilium Oecumenicum Vaticanum II, Decretum Optatam totius de institutione sacerdotali, 26.10.1965, Acta Apostolicae Sedis 58 (1966), p. 713-727.

6 R. Sobański, Zagadnienie wstepu do nauki prawa kanonicznego, Prawo Kanoniczne 17 (1974) no. 1-2, p. 6; M. Żurowski, Prawo Nowego Przymierza, Warszawa 1989, p. 7.

${ }^{7}$ R. Sobański, Kościót-prawo-zbawienie, Katowice 1979, s. 21.

${ }^{8}$ Cf. A. J. Maida, Visionary or Reactionary: the Canonist's Challenge to Create, CLSA Proceedings 39 (1977), p. 9.

${ }^{9}$ The main part of this article can be found in: P. Kroczek, The Art of Legislation: the Principles of Lawgiving in the Church, Kraków 2011, p. 11-19, where the problem of a model of the Church is discussed in the context of legislation.
} 


\section{Approach to Model in General}

Models are used to comprehend reality by its analogy to a created model. Attempts to get to know reality without them would be often in vain due to complexity of problems. It is a reason why models are of significant importance in science. ${ }^{10}$

The proper choice of a model for the object is a very complicated task. It requires taking into consideration many factors. The more aspects are considered and the more important they are, the better. Discussing the most effective way of using a model needs taking into account essential features of social phenomena and the specific subject of the research. The process of creating a model must be done very carefully. Needless to say, it is essential for the outcome of research. ${ }^{11}$

Looking from the outside perspective at the Church, it is just a community of people. So it seems that a good clue to understand the idea of a model of the Church can be taken from social sciences. In this field of science models are really essential. ${ }^{12}$

In social science, model is defined as an abstract representation, which helps to think and presents subject more clearly. It is, for instance, a simplified description of society or a part of society, which aids in understanding or studying it. ${ }^{13}$ Such model should reduce and structuralize social reality, assuming that some aspects of reality will not be taken into consideration. On the other hand, it does not mean any reduction or cutback. Any model should not be a sheer speculative idea but it must be taken from cognition of reality. This is condition of its usefulness. ${ }^{14}$

Of course, such a view is a simple reduction to external features only, but it brings about some clarification of general idea of a model of the Church. For the purpose of finding a model, it is enough to see the Church in this way. It must be underlined that sociological sciences help only to understand the idea of a model of the Church, not to comprehensively build it.

\footnotetext{
${ }^{10}$ For an informative introduction, see, for instance: P. Rothmaler, Introduction to Model Theory, Amsterdam 2000.

${ }^{11}$ J. Huber, Rational Choice Models in Sociology, The American Sociologist 28 (1997) no.

2, p. 42-53; B. Pabjan, The Use of Models in Sociology, Physica A, vol. 336, issue 1-2, p. $146-152$.

${ }^{12}$ W. Outhwaite, The Philosophy of Social Science, [in:] The Blackwell Companion to Social Theory, ed. B. S. Turner, Malden 1998, p. 91.

13 Cf. Entry: Model, [in:] A. G. Johnson, The Blackwell Dictionary of Sociology. A User's Guide to Sociological Language, Malden-Oxford 2000², p. 197.

${ }^{14}$ Cf. H. M. Blalock, The Formalization of Sociological Theory, [in:] Theoretical Sociology. Perspectives and Developments, ed. J. C. McKinney, E. A. Tiryakian, New York 1970, p. 275-281. See also: P. Sztompka, Opojecciu modelu $w$ socjologii, Studia Socjologiczne 1 (1968), p. 50.
} 


\section{Some Models of the Church}

There is an abundance of models of the Church. Some models are used rather unintentionally. ${ }^{15}$ They are results of the way of understanding the reality of the world where the schemas of known world institutions are transformed and used for understanding the Church. When R. Bellarmine said about the Church that the Church is a group of men as visible and palpable as that of the Roman people, or the Kingdom of France, or the Republic of Venice, ${ }^{16}$ he simply understood the Church like a state.

This understanding and derived from it definition of the Church as societas perfecta had serious consequences in canon law. It has become more than just an opinion of theologians or canon lawyers. It has a character of doctrine. ${ }^{17}$ For instance, Pope Leo XIII in Epistola Encyclica Immortale Dei $i^{18}$ taught that the Church no less than the state itself is a society perfect in its own nature and its own rights. ${ }^{19}$

Although, Code Iuris Canonici from 1917 did not use the term societas perfecta, Pope Benedict XV at the beginning of Constitutio Apostolica Providentissima Mater Ecclesia, by which he promulgated the code in question, said: "Providentissima Mater Ecclesia, ita a Conditore Christo constituta, ut omnibus instructa esset notis quae cuilibet perfectae societati congruunt, inde a suis primordiis, cum, Dominico obsequens mandato, docere ac regere omnes gentes incepit, aggressa est iam tum sacri ordinis virorum christianaeque plebis disciplinam datis legibus moderari ac tueri." ${ }^{20}$

In contrast, using the same unintentional method for building a model, that is, observing and analyzing the well-known institutions, R. Sohm saw the Church exclusively as a spiritual community of love and a purely charismatic movement. The Church according to him is a spiritual

\footnotetext{
15 R. Sobański, Model Kościoła-tajemnicy jako podstawa teorii prawa kościelnego, Prawo Kanoniczne 21 (1978) no. 1-2, p. 41.

${ }^{16}$ R. Bellarmine, De consillis et Ecclesia, 1, III, c. 2, [in:] R. Bellarmine, Opera omnia, Parisiis 1871, II, p. 75.

${ }^{17}$ See more: L. Gerosa, Interpretacja prawa w Kościele. Zasady, wzorce, wskazówki, transl. K. Kubis, A. Porębski, Kraków 2003, p. 40-41, ft. 11.

${ }^{18}$ Leo PP. XIII, Epistola Encyclica Immortale Dei de civitatum constitutione christiana, 1.11.1885, ASS 18 (1885), p. 161-180.

${ }^{19}$ Immortale Dei, p. 171: "Ad summam, sic agunt cum Ecclesia ut societatis perfectae genere et iuribus opinione detractis, plane similem habeant ceterarum communitatum, quas respublica continet: ob eamque rem si quid illa iuris, si quid possidet facultatis ad agendum legitimae, possidere dicitur concessu beneficioque principum civitati."

${ }^{20}$ Benedictus PP. XV, Constitutio Apostolica Providentissima Mater Ecclesia Codex Iuris Canonici promulgatur, 27.05.1917, Acta Apostolicae Sedis 9 (1917) II, p. 5. For more about the understanding of the Church as societas perfecta in teaching of the Church, see: R. Sobański, Kościót jako podmiot prawa. Elementy eklezjologii prawnej, Warszawa 1983, p. 36-39.
} 
congregation. The kingdom, which is established in the Church, is a spiritual kingdom formed not like a state or a political union. ${ }^{21}$ This scholar having this model in mind arrived at the conclusion that law and the Church are contradictory - "Das Wesen der Kirche ist geistlich, das Wesen des Rechtes ist weltlich. Das Wesen des Kirchenrechtes steht mit dem Wesen der Kirche in Widerspruch., ${ }^{22}$

There are models of the Church constructed purposely by taking some data from Sacred Scripture. Some models give valuable insights to ecclesiologists by describing the three Old Testament community models: 1) the pre-monarchic, called also "the new church start," 2) the monarchic, or the "temple community" and 3) the post-exilic, or the "textual community." ${ }^{23}$ Other models are based on figures of the Church constructed in the New Testament. ${ }^{24}$

The standard and very well-known work in the area of the Church models is A. Dulles's book Models of the Church. ${ }^{25}$ The author described five ways of understanding the Church using both mentioned methods:

1. The Church as an Institution defines the Church primarily in terms of its visible structures, especially the rights and powers of its officers.

2. The Church as the Mystical Communion where the Church is a mysterious and intimate spiritual union of people with God and each other through the Body of Christ. The unity is granted by bonds of creed, worship, and ecclesiastical fellowship.

3. The Church as Sacrament is a sign and transmitter of God's grace in the world and the visible presence of God on earth.

4. The Church as Herald is a kerygmatic model that emphasizes faith and proclamation and including the mission of the People of God, the baptized, to proclaim God's Word.

5. The Church as Servant asserts that the Church should consider itself as part of the total human family sharing the same concerns as the rest of men. It calls for dialogue with society and assisting persons in a variety of needs.

Later on in the revised and expanded edition of his work ${ }^{26}$ A. Dulles added the sixth model to this list:

\footnotetext{
${ }^{21}$ R. Sohm, Outlines of Church History, transl. M. Sinclair, London 1895, p. 24.

${ }^{22}$ R. Sohm, Kirchenrecht, vol. I, Die geschichtlichen Grundlagen, Leipzig 1923, p. 700: "The essence of the Church is spiritual. The essence of law is secular. The essence of church law is in opposition to the essence of the Church".

23 W. Brueggemann, Rethinking Church Models Through Scripture, Theology Today 48 (1991), p. 128-138.

${ }^{24}$ P. S. Minear, Images of the Church in the New Testament, Philadelphia 1960.

${ }^{25}$ A. Dulles, Models of the Church, New York 1974.

${ }^{26}$ A. Dulles, Models of the Church, Expanded Edition, New York 1987.
} 
6. The Church as a Community of Disciples that is including Catholics' sense of being formed by the Scriptures, acting lovingly, sharing in Jesus' mission and service, and being co-responsible for the Church's mission and identity. As A. Dulles notes, he finds precise expression of it in the writings of Pope John Paul II. ${ }^{27}$

The idea from the Second Vatican Council must be mentioned here. The Church is presented and named as: mysticum Christi Corpus (the Mystical Body of Christ, LG8,LG 23), Corpus Christi (the Body of Christ, $L G$ 32, LG 33), or Corpus Domini (the Body of the Lord, LG 17), Templum Spiritus Sancti (the Temple of the Holy Spirit, LG 17), Populum Dei (the People of God, $L G 11, L G 12, L G 13)$. All these names are to approach the mystery of the Church in many aspects and dimensions. They help to deepen self-awareness of the Church. ${ }^{28}$

In summation it can be repeated after one scholar: "There is no one single or normative model of church life. It is dangerous and distorting for the Church to opt for an absolutist model that it insists upon in every circumstance. Moreover, we are more prone to engage in such reductionism if we do not keep alive a conversation concerning competing and conflicting models. Or, to put it positively, models of the church must not be dictated by cultural reality, but they must be voiced and practiced in ways that take careful account of the particular time and circumstance into which God's people are called. Every model of the church must be critically contextual." ${ }^{29}$ Many models of the Church can be used for different purposes. The choice depends on the purpose and goals to be reached. By the metaphors, images, pictures, and models the inner nature of the Church can be made known ( $L G 6$ ).

\section{R. Sobański's Model of the Church as the Mystery}

R. Sobański worked out a model of the Church as the mystery. ${ }^{30}$ This model can be a basis for the study of law in the Church in accord with the reality of the Church. ${ }^{31}$ There are some points of departure to build up the model in question.

\footnotetext{
${ }^{27}$ A. Dulles, Models of the Church, Expanded Edition, New York $1987^{2}$, p. 206.

${ }^{28}$ W. Aymans, Die Kirche in der bilbischen Bildsprache, [in:] Handbuch des Katholischen Kirchenrechts, ed. J. Listl, H. Schmitz, Regensburg $1999^{2}$, p. 3-8.

29 W. Brueggemann, Rethinking Church Models Through Scripture, Theology Today 48 (1991), p. 129.

30 R. Sobański, Model Kościoła-tajemnicy jako podstawa teorii prawa kościelnego, Prawo Kanoniczne 21 (1978) no. 1-2, p. 39-60; R. Sobański, Kościót-prawo-zbawienie, Katowice 1979 , p. 54-77.

${ }^{31}$ Cf. R. Sobański, Model Kościoła-tajemnicy jako podstawa teorii prawa kościelnego, Prawo Kanoniczne 21 (1978) no. 1-2, p. 41.
} 
The first is that the cognition of the law of the Church does not mean knowing the specific law norms but understanding their significance and role. The proper perspective of the canon law is possible in optics of the Church and after prior understanding of her.

The next presumption is that any model in science is a combination of elements. Also, a model of the Church is built up like that. There are two important elements of the Church: visible and invisible. Supernatural and redemptive reality is invisible but it was revealed as a visible one on the earth. A good analogy for the Church's elements is the hypostatic union between two natures of Jesus Christ. The Church is a tool of redemption in analogy to human nature of Jesus Christ. But, as any analogy this one too has its limits.

The next point states that any model of the Church based only on a visible element, that is, on the sociological character of the Church is not acceptable for explaining the role of canon law, because it omits the divine element of the Church (cf. $L G 8$ ). Social element is important and should not be omitted, but it does not play a major role.

The Second Vatican Council teaches, and this is the next factor, that the Church is the mystery, established and continually sustained here on the earth by Jesus Christ. It is the community of faith, hope and charity. But, the society is also structured with hierarchical institutions and organs. The Church must not be considered as two separate realities: neither the visible assembly and the spiritual community, nor the earthly Church and the Church enriched with heavenly things. Rather they form one complex reality, which coalesces from a divine and a human element ( $L G$ 8). This is possible only in light of the Church as the mystery.

The last element is that the term "mystery" in the model of the Church should not be understood as something not cognizable or something secret. The mystery must be understood in terms of Constitutio dogmatica Lumen gentium. The mystery of the Church is cognizable, but only in the light of faith.

R. Sobański, on the basis of these assumptions, set up his model in the following steps ${ }^{32}$ :

1. The organism of the Church is like a natural social organism. It lives as community in many communities. It lives like any other society, that is, its members are organized and cooperate together. That is why it can be understood and described by historical or social methods.

\footnotetext{
32 R. Sobański, Model Kościoła-tajemnicy jako podstawa teorii prawa kościelnego, Prawo Kanoniczne 21 (1978) no. 1-2, p. 50-52.
} 
2. But the organism of the Church has not only social features. It is in a mutual connection with the Holy Spirit. It is not a hypostatic union but it is a union of action. The Holy Spirit works through the Church as agens principalis. The Church lives thanks to the Holy Spirit.

3. The Church in its actions is a tool for the Holy Spirit, so the activity of the Church and effectiveness of the work depends fully on the power of the Holy Spirit. But, on the other hand, it can be said that the effectiveness is in certain relation to the faithful and their readiness to join in cooperation. They are gifted by the Holy Spirit for the cooperation among themselves and between them and the Holy Spirit.

4. It leads to the conclusion that there is no single action taken by the Church not being inspired by the Holy Spirit, and there is no sociological dimension of the Church without significance for salvation.

5. The Holy Spirit works through the social organism of the Church, that is, through the faithful. As they co-work with the Holy Spirit, they keep their personal characteristics and qualities, and use them in the work. By this, the significance of human features is underlined and appreciated.

The model of the Church as the mystery is based on the connection between the Holy Spirit and social organism, and their mutual cooperation. The human and social features are the real value. The Church must not be limited only to the social element. But this element plays a significant role and is essential for substantial and methodological approach to the reality of the Church. It must not be seen as an independent body but only as an inseparable connection with the Holy Spirit. The Third Person of God works in the Church, for the Church, through the Church. Without the Holy Spirit, the tool that is the Church and its action would not have any significance for salvation.

But how is the Church working? In the Body [Church] the life of Christ is poured into the believers who, through the sacraments, are united in a hidden and real way to Christ who suffered and was glorified. The sacraments are followed by the proclamation of the Word. The two dimensions of the Church's works are of essence: the Sacrament and the Word (cf. can. 213 and $L G 7$ ). ${ }^{33}$

The two dimensions are not the only ones. Every action of the Church serves the salvation. Whatever the Church is doing, it is expressing God's will and fulfills God's plan for the world. It serves as "fermentum et veluti anima societatis humanae in Christo renovandae et in familiam Dei trans-

\footnotetext{
33 The two pillars were emphasized by K. Mörsdorf, Wort und Sakrament als Bauelemente der Kirchenverfassung, Archiv für katholisches Kirchenrecht 134 (1965), p. 72-79.
} 
formandae exsistit" (GS 40). ${ }^{34}$ It is certain that the Church has no proper mission in the political, economic or social order. "Missio quidem propria, quam Christus Ecclesiae suae concredidit, non est ordinis politici, oeconomici vel socialis: finis enim quem ei praefixit ordinis religiosi est. At sane ex hac ipsa missione religiosa munus, lux et vires fluunt quae communitati hominum secundum Legem divinam constituendae et firmandae inservire possunt" (GS 42). ${ }^{35}$

There are several arguments for choosing this model for studying law in the Church and dealing with it. First of all, the model does not limit cognition of the Church only to external phenomena. If it did this it would have nothing in common with theology. The model of the Church as the mystery exhorts taking into consideration the fact that the Church is an object of faith and faith must be taken as an essential factor in understanding both the Church and church law. The model focuses on the internal life of the Church and as a result of this it takes into consideration Church's external actions.

Secondly, R. Sobański is of the opinion that it is impossible to study law in separation from community, it is impossible to deal with the Church in separation from its faith. ${ }^{36}$ His model is very good in showing the presence of the law and its significance in the life of the Church in light of faith of the Church. Surely, the Church and its faith must be connected very tightly during the building of the model to avoid an accusation summarized in famous dictum: "Jesus foretold the Kingdom, and it was the Church that came."37

The next argument for this model follows the theological point of view and allows explaining the phenomenon of faith in the Church and the law as its outcome without resorting to categories or notions from social life or philosophical arguments, like ubi societas, ibi ius or bonum commune. The model is an endogenic one. Asking for help from the sources outside the Church to explain the presence and shape of law in the Church would be a mistake. ${ }^{38}$ The Church indeed has sociological features of community, but all in all it does not take its existence from human nature of people, but from the Holy Spirit. The relation of the Church

\footnotetext{
${ }^{34}$ GS 40: "a leaven and as a kind of soul for human society as it is to be renewed in Christ and transformed into God's family."

${ }^{35}$ GS 42: "The purpose, which God placed before the Church, is a religious one. But out of this religious mission itself comes a function, a light and an energy, which can serve to structure and consolidate the human community according to the divine law."

${ }^{36}$ R. Sobański, Kościót-prawo-zbawienie, Katowice 1979, p. 61.

${ }^{37}$ A. M. Loisy, The Gospel and the Church, transl. Ch. Home, New York 1904, p. 166.

${ }^{38}$ For further reference, see: R. Sobański, Kościót - prawo-zbawienie, Katowice 1979, p. $79-84$.
} 
to Jesus is not just a relation of a society to its founder. The relationship goes far deeper. Jesus is far more the Church's foundation than its founder. The Church is revealed as the work of the Father, the Son and the Holy Spirit. Its fundamental structure is Trinitarian. ${ }^{39}$ The exogenic models may diminish understanding of the Church and canon law.

\section{Ending}

Operating on the basis of a model, one can approach a very complex reality and handle it. The Church, having many dimensions, is rather a difficult object to comprehend. Usage of any model of the Church makes it possible to look closer at and thus to better understand the Church.

As far as the law of the Church is concerned, a model must be specific because there is a temptation to extrapolate understanding of any community to the community of the Church. Taking any model could lead to a situation in which too many important features of the Church would be omitted. In consequence, church law would be seen as any other regulation given for organizing life of society. It must be underlined that sociological dimension of the community is only a carrier of the mission of the Church.

A canon lawyer looking at the Church must not see a mere sociological organism built by human relation, but rather he must see the Church primarily as a community between God and men. It means that the external bond imposed by law means nothing, if there are no internal bonds. ${ }^{40}$ Having this in mind, a canonist must prefer a model of the Church that is appropriate for realization of his vocation in the $\mathrm{Church}^{41}$.

It seems that among many models of the Church, Sobański's model is a very important achievement in the realm of canon law. It can be used as a useful and working tool by anyone who wants to study church law.

\section{References}

\section{Normative sources}

Benedictus PP. XV, Constitutio Apostolica Providentissima Mater Ecclesia Codex Iuris Canonici promulgatur, 27.05.1917, Acta Apostolicae Sedis 9 (1917) II, p. 5-8.

\footnotetext{
${ }^{39}$ P. J. Huizing, Reflections on the System of Canon Law, The Jurist 42 (1982), p. 245-246.

${ }^{40}$ R. Sobański, De theologicis et sociologicis principiis theoriae iuris ecclesialis elaborandae, Periodica de re morali, canonica, liturgica 66 (1977), p. 674.

${ }^{41}$ For more about the vocation of a canonist in the Church and his work for the community, see: J. A. Coriden, The Canonist's Vocation and a new Church Order, The Jurist 51 (1991), p. 67-80; L. Örsy, In the Service of the Holy Spirit: the Ecclesial Vocation of the Canon Lawyers, [in:] L. Örsy, Receiving the Council: Theological and Canonical Insights and Debates, Collegeville 2009, p. 143-151; P. Kroczek, Modelowa wizja pracy kanonisty, Bielsko-Żywieckie Studia Teologiczne 10 (2009), p. 217-228.
} 
Codex Iuris Canonici auctoritate Ioannis Pauli PP. II promulgatus, 25.01.1983, AAS 75 (1983) II, p. 1-301.

Leo PP. XIII, Epistola Encyclica Immortale Dei de civitatum constitutione christiana, 1.11.1885, ASS 18 (1885), p. 161-180.

Praefatio to Codex Iuris Canonici auctoritate Ioannis Pauli PP. II promulgatus, Acta Apostolicae Sedis 75 (1983) II, p. XVII-XXX.

Sacrosanctum Concilium Oecumenicum Vaticanum II, Constitutio dogmatica Lumen gentium de Ecclesia, 21.11.1964, Acta Apostolicae Sedis 57 (1965), p. 5-75.

Sacrosanctum Concilium Oecumenicum Vaticanum II, Decretum Optatam totius de institutione sacerdotali, 26.10.1965, Acta Apostolicae Sedis 58 (1966), p. 713-727.

\section{Literature}

Bellarmine, R., Opera omnia, vol. II, Parisiis 1871.

Blalock, H. M., The Formalization of Sociological Theory, [in:] Theoretical Sociology. Perspectives and Developments, ed. J. C. McKinney, E. A. Tiryakian, New York 1970, p. 275-281.

Brueggemann, W., Rethinking Church Models Through Scripture, Theology Today 48 (1991), p. 128-138.

Coriden, J. A., The Canonist's Vocation and a new Church Order, The Jurist 51 (1991), p. 67-80.

Dulles, A., Models of the Church, Expanded Edition, New York $1987^{2}$.

Dulles, A., Models of the Church, New York $1974^{1}$.

Gerosa, L., Interpretacja prawa w Kościele. Zasady, wzorce, wskazówki, transl. K. Kubis, A. Porębski, Kraków 2003.

Handbuch des Katbolischen Kirchenrechts, ed. J. Listl, H. Schmitz, Regensburg $1999^{2}$.

Huber, J., Rational Choice Models in Sociology, The American Sociologist 28 (1997) no. 2, p. 42-53.

Huizing, P. J., Reflections on the System of Canon Law, The Jurist 42 (1982), p. 239-276.

Johnson, A. G., The Blackwell Dictionary of Sociology. A User's Guide to Sociological Language, Malden-Oxford $2000^{2}$.

Kroczek, P., Modelowa wizja pracy kanonisty, Bielsko-Żywieckie Studia Teologiczne 10 (2009), p. 217-228.

Kroczek, P., The Art of Legislation: the Principles of Lawgiving in the Church, Kraków 2011.

Loisy, A. M., The Gospel and the Church, transl. Ch. Home, New York 1904.

Maida, A. J., Visionary or Reactionary: the Canonist's Challenge to Create, CLSA Proceedings 39 (1977), p. 1-9.

Minear, P. S., Images of the Church in the New Testament, Philadelphia 1960. 
Mörsdorf, K., Wort und Sakrament als Bauelemente der Kirchenverfassung, Archiv für katholisches Kirchenrecht 134 (1965), p. 72-79.

Örsy, L., In the Service of the Holy Spirit: the Ecclesial Vocation of the Canon Lawyers, [in:] L. Örsy, Receiving the Council: Theological and Canonical Insights and Debates, Collegeville 2009, p. 143-51.

Outhwaite, W., The Philosophy of Social Science, [in:] The Blackwell Companion to Social Theory, ed. B. S. Turner, Malden 1998, p. 47-70.

Pabjan, B., The Use of Models in Sociology, Physica A, vol. 336, issue 1-2, p. 146-152.

Rothmaler, P., Introduction to Model Theory, Amsterdam 2000. Slodička, A., Theologia fundamentalis de Ecclesia, Prešov 2005.

Sobański, R., De theologicis et sociologicis principiis theoriae iuris ecclesialis elaborandae, Periodica de re morali, canonica, liturgica 66 (1977), p. 674.

Sobański, R., Kościót jako podmiot prawa. Elementy eklezjologii prawnej, Warszawa 1983.

Sobański, R., Kościót-prawo-zbawienie, Katowice 1979.

Sobański, R., Model Kościota-tajemnicy jako podstawa teorii prawa kościelnego, Prawo Kanoniczne 21 (1978) no. 1-2, p. 39-60.

Sobański, R., Podstawy prawa Kościelnego, Prawo Kanoniczne 34 (1991), no. 1-2, p. 13-24.

Sobański, R., Zagadnienie wstepu do nauki prawa kanonicznego, Prawo Kanoniczne 17 (1974) no. 1-2, p. 3-30.

Sohm, R., Kirchenrecht, vol. I, Die geschichtlichen Grundlagen, Leipzig 1923.

Sohm, R., Outlines of Church History, transl. M. Sinclair, London 1895.

Sztompka, P., O pojęciu modelu w socjologii, Studia Socjologiczne 1 (1968), p. $27-58$.

Żurowski, M., Prawo Nowego Przymierza, Warszawa 1989. 